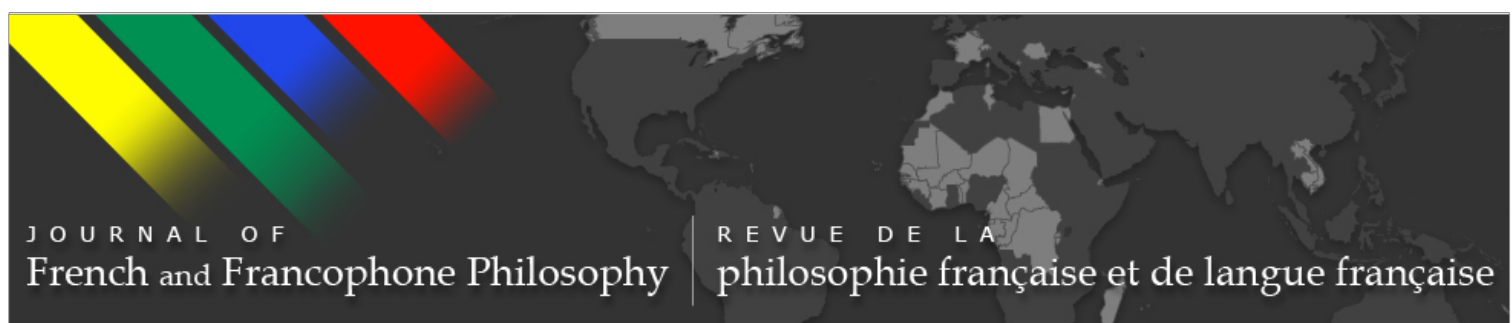

\title{
Stockholm
}

\section{Going Beyond the Human through Dance}

\section{Julia Kristeva}

Journal of French and Francophone Philosophy - Revue de la philosophie française et de langue française, Vol XXI, No 1 (2013) pp 1-12

\author{
Vol XXI, No 1 (2013) \\ ISSN 1936-6280 (print) \\ ISSN 2155-1162 (online) \\ DOI 10.5195/jffp.2013.571 \\ www.jffp.org
}

\section{(oc) $\overline{\text { EY-NG-ND }}$}

This work is licensed under a Creative Commons Attribution-Noncommercial-No Derivative Works 3.0 United States License.

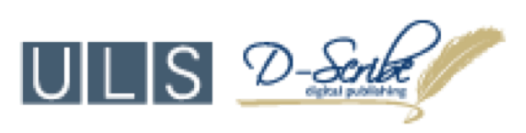

This journal is operated by the University Library System of the University of Pittsburgh as part of its D-Scribe Digital Publishing Program, and is co-sponsored by the University of Pittsburgh Press 


\title{
Stockholm
}

\section{Going Beyond the Human through Dance}

\author{
Julia Kristeva
}

Université Paris Diderot - Paris 7

As I am by no means a specialist of dance, your invitation is both an honour and a surprise. I came up with my own explanation: you've called upon me perhaps because I DANCE with concepts, disciplines and genres in my essays and novels! I thank you then, for having invited me to consider that my contributions to contemporary thought: intertextuality, strangeness, the significance of language, the subject-in-process, abjection and reliance - to name only a few - can be understood and practised as dance, which as I see it, is this nimble movement of incorporated thought.

I say: "nimble movement of incorporated thought," and in risking this definition of dance, I still cannot promise to construct a working theory of your practice. Perhaps this will be possible after having clarified several preliminary ideas, far outside of your field. Yet working in its proximity and attentive to your research, I ask myself: If dance or rather dances in the plural have always accompanied religious rites and their offshoots, if men and women's dancing is inseparable from the experience of this Homo Religiosus which is Homo Sapiens, how is it possible to dance if God is dead? In saying "God is dead" I am referring to an event that happened in Europe - and nowhere else - which cut ties with religious tradition. An unprecedented event whose way was paved by the Greco-Judeo-Christian tradition. But "God is dead" also means that some use religion as a political tool if not a political weapon, as in the case of religious fundamentalism. Hannah Arendt already established that those who use God for political aims are just as nihilistic as the self-declared nihilists, if not more.

And what about conflicts between religions? What about the junction and elucidation of the need to believe and of the desire to know? That is the question I investigate in This Incredible Need to Believe (2007), and it is THE question of the $21^{\text {st }}$ century. We cannot respond to it without continuously refounding this other space, which detached itself from the religious continent, and which is precisely secularization or humanism. It was built in

Journal of French and Francophone Philosophy | Revue de la philosophie française et de langue française Vol XXI, No 1 (2013) | www.jffp.org | DOI 10.5195/jffp.2013.571 
Europe starting in the Renaissance and developed through the $18^{\text {th }}$ century with Erasmus, Diderot, Voltaire, Rousseau, Goethe and many other rebels up to Freud and his successors who have inspired my reflexion.

I understand humanism in the Nietzschean sense of a "transvaluation of values" that puts "a big question mark on matters of weighty seriousness." Such work is endless, exorbitant and long-term. It is a matter of taking the crisis that is shaking our world seriously. We are undergoing not only an economic, political and social crisis but an existential one in which we are confronted with a major unknown: What is a man? What is a woman?

The interminable response to this question associates, I believe, today's crisis with the crisis of Homo Sapiens. Concretely speaking, it's a question of human identity in general, and subsequently of the crisis of our multiple identities: sexual, ethnic, racial, national, religious, familial, etc. This crisis calls upon the human sciences, which developed after the disintegration of the theological continent two centuries ago. But this response depends equally on our possibility -- or not -- of creating new languages: new literature, new painting, new dance.

In the $13^{\text {th }}$ and $14^{\text {th }}$ centuries, Dante Alighieri (1265-1321) in his Divine Comedy (cantica I, 69) looked for a language capable of "exceeding the human": "transhumanar" was the term he used, a neologism representative of what is called his "new style." Rather than the most exigent theory, I hope it will be dance that speaks one of the new languages of the human comedy. Dance as a radical gesture of this transhumanar which humanity needs, if we refuse to wallow in this endemic, inevitable crisis that the growth of technology and virtual finance has imposed on men and women, and if, on the contrary, we want to sense the seeds germinating while awaiting the much desired renaissance to come.

In this spirit, I must first specify what I mean by humanism. The ambition to define it has often given rise to fabulous claims, or even disappointment when its meaning was misconstrued, leading to impasses, impostures, even crimes.

Invited by Pope Benedict the XVIth to a recent interreligious meeting for peace in Assisi in October 2011, as a humanist at the head of a delegation of non-believers, and this for the first time in the long history of religions, I developed ten principles of humanism which I would like to introduce to you.

I will then maintain that new political actors are incarnating and realizing the refoundation of humanism which the globalized world direly needs. I will take as examples two of these experiences which cruelly lack a means of expression in today's codes of humanism: adolescents in want of ideals and maternal passion at the crossroads of biology and meaning.

Journal of French and Francophone Philosophy | Revue de la philosophie française et de langue française Vol XXI, No 1 (2013) | http://www.jffp.org | DOI 10.5195/jffp.2013.571 
At these crossroads of body and meaning, of biology and sublimation, it is perhaps dance more than other trans-linguistic experience that informs and accompanies the process of transhumanization as it counters the crisis and exceeds the impending threat of apocalypse.

\section{Ten Principles for the Humanism of the Twenty-First Century}

What is humanism? A great question mark on the most serious of issues? This reality is a product of the European, Greco- Judeo-Christian tradition as I already mentioned. And at the same time it continues to promise, to disappoint, to re-constitute itself. Here I stray a bit from dance, but it's with the conviction that the deeper sense of your research converges with the agitation [le soubresaut] at the very depths of our civilization.

1. The humanism of the twenty-first century is not a theomorphism. Neither "value" nor ulterior "goal," Man with a capital M does not exist. After the Holocaust and the Gulags, humanism has a duty to remind men and women that we are not the only legislators, but it is uniquely through the continual questioning of our personal, historical and social situation that we can make decision for society and history. Today, far from deglobalization, it is necessary to invent new international rules to regulate and control finance and the global economy, and finally to create a world authority based on universal ethics and solidarity.

2. Humanism is a process of permanent refoundation that develops through the ruptures that are innovations. Memory does not regard the past: the Bible, the Gospels, the Koran, the Rig Veda, the Tao, live in the present. In order that humanism might develop and re-found itself, the moment has come to reinterpret the moral codes built throughout history: without weakening them, in order to problematize them, to renew them in the face of new singularities.

3. Humanism is a feminism. The liberation of desires could only lead to the emancipation of women. The battle for economic, legal and political parity necessitates a new reflection on the choice and responsibility of motherhood. Secularization is still the only civilization that lacks a discourse on motherhood. This passionate bond between mother and child, through which biology becomes meaning, alterity, and word, is a "reliance" that, while different from the paternal function and from religiosity, completes the full participation in the humanist ethic.

4. In order that the desires of men and women may be rekindled, Humanism teaches us to take care of them. The loving care for each other, the care of the earth, the young, the sick, the disabled, the elderly dependents, constitute inner experiences that create new proximities and surprising solidarity. We have no other way to experience the

Journal of French and Francophone Philosophy | Revue de la philosophie française et de langue française 
anthropological revolution, already announced by the leaps of the sciences, from uncontrollable processes of technology and finance, and the inability of the pyramidal democratic model to properly channel these innovations.

5. Man does not make history, but we are history. For the first time, Homo Sapiens is capable of destroying the earth and himself in the name of his beliefs, religions or ideologies. Similarly, for the first time men and women are able to reassess in total transparency the constituent religiosity of the human being. But the hypothesis of destruction is not the only possible one. No one knows what kind of human beings will succeed us, we who are engaged in this unprecedented anthropological and cosmic transvaluation. The re-founding of humanism is not a providential dogma, nor an intellectual game, it is a gamble.

The age of suspicion is no longer enough. Faced with increasingly grave crisis and threats, the time has come to gamble. We must dare to bet on the continuous renewal of the capacity of men and women to listen and learn together. So that, in the "multiverse" surrounded by a void, mankind can continue to pursue his creative destiny for a long time to come.

In this multiverse, there are two new political actors that speak very particularly to creators such as yourselves regarding this language that surpasses the human - this language which I believe dance to be: these two actors are adolescents and maternal passion.

\section{Adolescence: A Syndrome of Ideality}

1. As opposed to the child, a polymorphic pervert, according to Freud - the child who wants to know where babies come from and who Freud compares to a "laboratory researcher" - the adolescent is a believer. The adolescent is not a "researcher" in a laboratory but a believer. We are all adolescents when we are enthralled by the absolute. Freud did not preoccupy himself with adolescents because he was himself a firm non-believer, the most irreligious person who ever existed. Faith implies a passion for what psychoanalysis calls an "object relation": faith is potentially fundamentalist, as is the adolescent. Romeo and Juliette are excellent examples of this; I'll come back to them later. However, because the sadomasochistic nature of our drives and desires is inevitable, adolescent belief that the Ideal Object exists is continually threatened.

I will assert then, that the adolescent is a believer of the object relation and/or of its impossibility. Thus formulated, the question implies a parameter that we have trouble taking seriously: this parameter is ideality.

2. What is the ideality syndrome? The adolescent Oedipus complex is violent because it operates on the carrier wave of idealization. The

Journal of French and Francophone Philosophy | Revue de la philosophie française et de langue française

Vol XXI, No 1 (2013) | http://www.jffp.org | DOI 10.5195/jffp.2013.571 
adolescent, whose psyché is rooted in the polymorphous perversity of the young child, separates from the parental couple by replacing it with a new model. In doing so, the narcissism of the Ego, tied up with its ideals, overflows the object and gives way to the amorous passion specific to the drive-ideality intrication.

The intensity of this new satisfaction is procured thanks to something not sufficiently brought out in Freudian theory: namely, the inclusion of the object in narcissism happens in the guise of belief. The adolescent acquires the certainty that there exists - an absolute satisfaction. That he or she can erase the original and tragic Oedipus complex, and rush towards a new love that will open the doors to new paradises. Images, ideologies, different forms of knowledge and existential models are all brought into play to shore up an idealized narcissism unfurling over others and which surpasses in strength all former ideals. Ideality dominates the adolescent unconscious: adolescent drive and pleasure are structured not only as a language but as an ideality.

Let me sum this up as follows: The belief that there exists an ideal object (be it a partner, a profession or a creation), is accompanied by the absolute belief that the parental couple must be surpassed and even abolished so that the adolescent subject can escape into an idealized, paradisiacal variant of absolute satisfaction. The Judeo-Christian paradise is an adolescent creation: the adolescent takes pleasure in the paradise syndrome, which conversely, can also become a source of suffering if absolute ideality turns into cruel persecution. Because he or she believes that the other, surpassing the parental other, not only exists but that he or she provides absolute satisfaction, the adolescent believes that the Great Other - God - exists, and is pleasure itself. The slightest disappointment of this ideality syndrome casts the adolescent into the ruins of paradise and leads toward delinquent conduct.

\section{Believers and Nihilists}

We understand that, structured by idealization, adolescence is constituted through the malady of ideality: Why? Structured by a propensity for belief, the adolescent is easily carried away by enthusiasm, romanticism and even fanaticism. The adolescent is a mystic of the Object of love. When this fantasy fails to direct toward a process of sublimation (school, profession, vocation), the failure of the paradise syndrome inevitably leads to depression and takes the common form of boredom: "If I don't have Everything, I get bored"; this opens the way to delinquent conduct. But this conduct is merely the flip side of the malady of ideality, since the need for ideality persists beneath this delinquency and supports aggressive behavior. It in no way signals the abolition or the on-going destruction of ideality.

Journal of French and Francophone Philosophy | Revue de la philosophie française et de langue française Vol XXI, Nol (2013) | http://www.jffp.org | DOI 10.5195/jffp.2013.571 
Thus drug addiction abolishes the conscience but fulfills the belief in the absolute of orgasmic regression within the experience of hallucinatory pleasure.

On the other hand, anorexic behavior breaks with the maternal line and reveals the young anorexic woman's battle against femininity. Yet this selfdestruction, this death-wish operates to the benefit of an over-investment in the "hard-lined" body, which echoes back to the fantasy of an absolute spirituality. Through this fantasy the entire body disappears in a Beyond, charged with paternal connotations.

\section{Romeo and Juliet: The Ideal and Impossible Couple}

Let's take another example. The perpetuation of the paradise syndrome, notably in the bourgeois couple, has become a pillar of the established now globalized social order maintained by hackneyed television "soap operas" and magnified by "gossip" magazines. This ideal and thus impossible couple is at the heart of classical ballet and persists in modern dance - its prototypes are Adam and Eve, Dante and Beatrice at the firmament of heaven, and Romeo and Juliet.

In our culture, Shakespeare's (1564-1616) Romeo and Juliet (1591 or 1594) is the paradigm of this fantastical construction. The mutual idealization that two adolescents share is experienced as a rejection of parental authority: Romeo and Juliet's love for one another is fueled all the more by the fact that their ideal couple defies the Montague and Capulet clans who hate one another and engage in a merciless feud. This young couple's ideal is defiant and secret as all adolescent acts aspire to be. Moreover, the reciprocal idealization of the two lovers is perceived by all as "fate." What is fate? I'd say that fate is the adolescent belief that one's pleasure is legitimate and justified, although it is impossible. Several lines of these Shakespearean adolescents resonate with Marlowe: "It lies not in our power to love, or hate, For will in us is over-rul'd by fate." The fate of idealized relationships, both indulged and impossible. Nevertheless, as Shakespeare's genius powerfully reveals, the belief that the Ideal Other inevitably exists, is fragile and has difficulty withstanding the assaults of the adolescent's latent polymorphous perversity remaining from childhood. Here are two examples, which serve to prove this. First, beneath the exalted discourse of the lovers one perceives sadomasochist desire. Juliette literally cuts up Romeo's body at nightfall: "Come, gentle night/come, loving, black-brow'd night./ Give me my Romeo; and when he shall die/ Take him and cut him out in little stars ..." (III, II, 9-25). As for Romeo, his jealousy emerges as a fatal pleasure in stabbing his male rivals: “O I am fortune's fool!," he cries out as he stabs Tybalt and Paris. In the end, this paradisiacal ideal of the couple turns out to be impossible. Romeo and Juliet die: in 1591 or in 1594 Shakespeare was no longer an adolescent. He had left his wife Anne Hathaway, and his son, Hamnet, had just died. "Romeo and Juliet," his ninth play in the second

Journal of French and Francophone Philosophy | Revue de la philosophie française et de langue française

Vol XXI, No 1 (2013) | http://www.jffp.org | DOI 10.5195/jffp.2013.571 
cycle of his lyrical masterpieces (along with A Midsummer Night's Dream), reads as a farewell to the adolescent belief that the Ideal Object exists.

Let's return to the current state of affairs and ask ourselves: how can the psychoanalyst, as well as the dancer and the spectator, take into account the fact that the unconscious of the adolescent believer is constructed as a highrisk ideality? Civilizations commonly referred to as primitive have long used initiation rites to assert symbolic authority (divine for the invisible world, political for this world) and to justify the acting out of what we would qualify today as perverse by condoning initiatory sexual practices. In our Western culture, notably in medieval Christianity, mortification rituals and excessive fasting channeled the anorexic and sadomasochistic behaviors of adolescents, and in doing so, either downplayed or glorified them. In yet another way, this time secular, what seems to me to be an imaginary elaboration of the adolescent crisis is the birth of the European novel shaped in the Renaissance around the adolescent character. The young page serving his Lady is a recurrent trope of the courtly romance in which a complex range of homosexual relations, more or less developed, are played out.

Those are some solutions from the past, but today the question for psychoanalysis is: are we able to innovate when confronted with adolescent crises? And if so, how does psychoanalysis avoid the pitfall of stabilizing the crisis of ideality into the married couple, that temporary happy end of the bourgeois novel? Even today, popular literature continues to draw from this narrative logic developed during the Renaissance. Even hard-core sex fails to break out of this logic and is easily assimilated into it. Compared to the diverse ways of dealing with adolescent ideality that have preceded us, we might wonder if psychoanalysis is indeed innovative. And if so, how?

Adolescents come to us because they need us to recognize their ideality syndrome. We must articulate and share our understanding of it if we are to comprehend and accurately interpret the delinquent behavior of the adolescent in crisis itself as a source of extreme jouissance - and in search of a simulacrum of paradise. Only later should the analyst attempt to point out the negative aspects of this behavior which is necessarily a revolt: a revolt is of the Oedipal or Oresterean order. In other words, only the analyst's capacity to recognize and to name the idealizing course of adolescent drives will provide a credible and effective transference - and thus be capable of metabolizing the need to believe not through nihilist acting out, but through the pleasure that comes with thinking, questioning and analyzing. And to accompany his rebellions, his doubts, and his malaises in this way while conserving this universal component, this need to believe, which structures the adolescent.

As I tell you about how the analyst is confronted with the adolescent's need to believe, I encourage you to think about how dance can respond in its

Journal of French and Francophone Philosophy | Revue de la philosophie française et de langue française Vol XXI, Nol (2013) | http://www.jffp.org | DOI 10.5195/jffp.2013.571 
own particular way to these same needs manifested by adolescent malaise in our civilization.

In doing so, we would be better able to interpret the variants of our civilization's new malaise and this new renaissance of the "need to believe" which is an unexpected dimension underlying this crisis. This is a need which everybody shares, for there is in each of us a perpetual adolescent.

\section{Motherhood Today}

Secularization is the only civilization to lack a discourse on motherhood. We think we understand what a Jewish or a Christian mother is, but what about a modern mother? What is she in this space between the lover, the working woman, and the activist for women's liberation and artificial reproduction, or, on the contrary, returning to the protective values of the traditional family?

Everyday the life sciences and obstetrics are gaining increased mastery over the enigma of gestation which, due to its very status as an enigma, formerly conferred power upon the mother while at the same time anxiously taking it away. And yet feminine fertility and pregnancy not only continue to fascinate our collective imagination, but also serve as a sanctuary for the sacred. The position of modern religiosity would hold the " beyond" as no longer being above our heads but in the womb. Today motherhood is imbued with what remains of religious feeling.

Contemporary psychoanalysis seeks to shed some light on maternal passion. At an international conference on psychoanalysis, I recently proposed the existence of a maternal eroticism that I call reliance. This word, in French, carries echoes of the word "lien," to link or to connect, and confiance, trust or confidence, as well as an alternative to religion (religionreliance). Between biology and sense, attachment and expulsion, love and hate, violent influence and generous transmission, maternal reliance is a surprising and necessary version of ethics we might call a herethic.

Maternal passion understood as "reliance" is perhaps the only passion that is not virtual and subject to spectacular manipulation and which constitutes the prototype for the love relation. It begins with the pregnant woman's passion for herself, a "herself" reflecting a reinforced and destabilized narcissism: the pregnant woman is losing her identity, for, in the wake of the lover-father's intervention, she splits in two, harboring an unknown third person, a shapeless pre-object. In other words, though dominated by narcissism, this initial maternal passion remains triangular. Nevertheless, the absent or inward looking gaze of the Madonnas with child of the Italian Renaissance, such as those by Giovanni Bellini, openly show what many of us know: that the pregnant woman "looks" at the father and the world without "seeing" him; she is elsewhere.

Journal of French and Francophone Philosophy | Revue de la philosophie française et de langue française Vol XXI, No 1 (2013) | http://www.jffp.org | DOI 10.5195/jffp.2013.571 
The first stage of this inwardly turned passion is followed by the mother's passion for a new subject, her child: provided that the child stops being her double and that she detaches herself so that the child can gain autonomy. This motion of expulsion, of detachment is essential. This is a way of saying that, from the outset, maternal passion is inhabited by the negative.

Freud was convinced that "loving thy neighbor as thyself" was an illusion, a pious wish of the Evangelists. Indeed, such love has only been attained by Saint Francis and other rare mystics like him. I believe that "loving one's neighbor as oneself" brings us back to this enigma - even more obscure than the mystery of gestation - of what the "good enough mother" is. It is she who allows the infans to create a transitional space (Winnicott), a space which enables the infant to think. Because it is not easy to love oneself: generally speaking, it is either impossible or else tragic. However, the "good enough mother" succeeds in loving her child as herself, and then as another self.

On the cultural level, I've noticed that in cases of "feminine genius" (be it outside of the maternal experience and in ventures as diverse as those undertaken by Hannah Arendt, Melanie Klein and Colette) there is an object relation from the very beginning of the psychic life. This is quite different from Freud's postulation of a "narcissism without an object" at birth and from "masculine genius" (philosophers, artists) which is more directed towards solipsistic incantations and the dramas of subjectivity per se. And yet to maintain that for a woman, and even more so for a mother, there is an Other early on in the psychic life is hardly idyllic. For this precocious object relation is characterized by instability, an instability likely to turn into manic exaltation or depression and aggression: him or me, projectionidentification.

This drama nevertheless has a positive side, as this passion can allow the mother to create a possible bond with the other, to elaborate the passionate destructiveness underlying all types of relations which motherhood in particular makes us experience all the more sharply ("I love him and I hate him"). This is why, with its violent emotions of love and hate, motherhood resembles an analysis of borderline states and perversions. I share the opinions of some authors, for whom feminine sexuality takes refuge in motherhood to live out its perversion and madness, which can also be a way of enabling their working-through madness. Seduction, fetishizing the child's body and its accessories, emotional outbursts, manic states - it isn't rare that the very possibility of thinking is threatened by the mother's passion. It then takes on a more lethal meaning.

However, a certain detachment-depassioning takes place in most cases. And it's from this that maternal love derives its definitive psychic and vital support. Because most mothers are not in analysis, one has to concede that there is something in the very structure of the mother's experience that encourages this metabolism of passion by depassioning. I suggest considering

Journal of French and Francophone Philosophy | Revue de la philosophie française et de langue française Vol XXI, No I (2013) | http://www.jffp.org | DOI 10.5195/jffp.2013.571 
three factors within maternal passion itself: the place of the father, time, and language acquisition.

I will say only a few words about time and language in maternal passion. The child's language acquisition implies that the mother also re-learns language. In the projective identification of the mother and child, the mother inhabits the mouth, lungs and digestive tube of her baby and by accompanying his Echolalia, she leads him towards signs, sentences, stories: hence infans becomes a child, a speaking subject. Each mother accomplishes in her own way the Proustian search for "time past."

As for temporality, referring as it does in Western philosophy to the time of death (which also haunts the experience of motherhood, of course) here, in the case of motherhood, it is dominated by another caesura: that of beginning. Of course, both parents experience conception and giving birth as initial acts marking a beginning. Yet the mother feels it most strongly because of the importance of her own body's involvement in the process. For her, this new beginning that is birth is not only a conjuration of death. Philosophers have taught us that the logic of freedom does not reside in transgression, as one might readily suppose, but precisely in the capacity to begin. I call this maternal experience of temporality, which is neither the instant nor the irretrievable flow of time (which preoccupies men, who tend to be more obsessive than women), duration by means of new beginnings. Being free means having the courage to begin anew: such is the philosophy of motherhood.

So what are the excesses which underlie maternal passion? The temporality of maternal passion can be viewed analytically as a kind of detachment in relation to the sole object, as an invitation to the plurality of beings and relations; it can be seen as the source of "depassioning" and freedom, which is ultimately freedom from passion. We see that while being the prototype of human passion, maternal passion is also the prototype of the letting go of passion which allows us to take our distance in relation to the two tormentors of the human psyche which are sexual drives and the object of love.

This brings me to the maternal passion's capacity for sublimation. It is because the maternal passion is a continual sublimation that creativity is made possible for the child.

Freud had observed a cycle of sublimation in the emission and reception of jokes. Indeed, the author of the joke neutralizes his affects by communicating only his surface thought: he stands back from his sexual drives and latent thoughts and only invests his listener's reaction. The storyteller's pleasure is doubled when the listener understands the hidden meaning of the joke, be it a trap! The listener experiences the ambiguous pleasure of understanding that he was trapped. This cycle of sublimation is comparable to what happens when mother and child exchange words and thoughts. For this exchange involves the emission of "enigmatic signifiers,"

Journal of French and Francophone Philosophy | Revue de la philosophie française et de langue française

Vol XXI, No 1 (2013) | http://www.jffp.org | DOI 10.5195/jffp.2013.571 
preverbal or verbal, by the mother; the withdrawal of the mother's sexual drives, her attentiveness to the reaction of her child alone; and the surplus of pleasure created, or the encouragement given to the child's response. The mother does not invest in her own message, but only the child's response from which she procures even greater jouissance and which in turn she magnifies and encourages.

Those who claim that maternal passion lacks humor are mistaken: if mothers can transform their hold on the child into a sublimatory cycle resembling witticism and which promotes the pleasure of thinking, they are living proof of Hegel's claim that women are "the eternal irony of the community."

To put it differently, by her progressive depassioning and or by her aptitude for sublimation, the mother allows her child to represent not the mother, but the mother's absence: if and only if she leaves the child free to appropriate maternal thought by recreating it in his own way of thinkingrepresenting. The "good enough mother" would be she who knows how to leave, to make room for pleasure, for the child, for thought. To leave room, in other words, to disappear.

Thus a kind of symbolic matricide operates through the child's acquisition of language and thought, which diminishes his need to take pleasure from his mother's body; he comes to find pleasure in thinking, first with his mother, as far as the intermittent nature of maternal thought permits, then alone, in her stead.

We've seen maternal passion as a cleft between the mother's hold over her child and sublimation. This division makes the risk of madness ever present, and yet this very risk offers a perpetual chance for culture. Religious myths spin their webs around this divide. In the Bible the woman is a "hole" (such is the meaning of the word "woman" - nekayva - in Hebrew) and a queen; the Virgin is a "hole" in the Christian trinity father/son/holy ghost and a Queen of the Church. Through these imaginary constructions, religions address this maternal division: by recognizing it, they perpetuated it but also found a way of balancing it. A kind of working-through of maternal madness came of this, one which made possible the existence of a humanity endowed with a complex psychic functioning, capable of having an inner life and of being creative in the outer world.

On the contrary, by turning all our attention on the biological and social aspects of motherhood as well as on sexual freedom and equality, we have become the first civilization which lacks a discourse on the complexity of motherhood. My dream is that the arguments I'm trying to develop here will help to remedy this lack, that they will stimulate mothers and those who accompany them to sharpen our understanding of this passion, pregnant with madness and sublimity. This is what motherhood lacks today.

Journal of French and Francophone Philosophy | Revue de la philosophie française et de langue française Vol XXI, Nol (2013) | http://www.jffp.org | DOI 10.5195/jffp.2013.571 
The adolescent and the mother are two eternal actors in human existence that reveal themselves to be decisive actors in this transhumanar, in this surpassing of the human that concerns us at the beginning of this third millennium. By incarnating their dramatic experiences, dance could perhaps accompany them with the necessary delicacy that is lacking in contemporary ethics and politics. The refoundation of humanism necessitates the revelation of your art - through the gravity of its buoyancy. Thank you for having given me the occasion to remind you of this.

Journal of French and Francophone Philosophy | Revue de la philosophie française et de langue française Vol XXI, No 1 (2013) | http://www.jffp.org | DOI 10.5195/jffp.2013.571 